CORRECTION

\title{
Correction to: School nutrition laws in the US: do they influence obesity among youth in a racially/ethnically diverse state?
}

Emma V. Sanchez-Vaznaugh (D), Mika Matsuzaki, Paula Braveman, Maria Elena Acosta, Kelsey Alexovitz, James F. Sallis, Karen E. Peterson and Brisa N. Sánchez

(c) The Author(s) 2021

International Journal of Obesity (2021) 45:2688; https://doi.org/10.1038/s41366-021-00932-0

Correction to: International Journal of Obesity https://doi.org/ 10.1038/s41366-021-00900-8, published online 20 July 2021

The original version of this article unfortunately contained a mistake in the legends of Figs. 1 and 5. The additional sentence to fig. legend 1 is: The color lines represent each of the racial/ethnic groups: Purple $=$ African American; Red $=$ Asian; Green $=$ Latino; Blue $=$ White. The additional sentence to fig. legend 5 is: The color lines represent each of the racial/ethnic groups: Purple $=$ African American; Red = Asian; Green = Latino. The journal apologizes for the omission of the legends. The original article has been corrected per author's request.

\begin{abstract}
(c) (i) Open Access This article is licensed under a Creative Commons Attribution 4.0 International License, which permits use, sharing,
adaptation, distribution and reproduction in any medium or format, as long as you give appropriate credit to the original author(s) and the source, provide a link to the Creative Commons license, and indicate if changes were made. The images or other third party material in this article are included in the article's Creative Commons license, unless indicated otherwise in a credit line to the material. If material is not included in the article's Creative Commons license and your intended use is not permitted by statutory regulation or exceeds the permitted use, you will need to obtain permission directly from the copyright holder. To view a copy of this license, visit http://creativecommons.org/licenses/by/4.0/.
\end{abstract}

(c) The Author(s) 2021 